\section{Impact of Histochemistry on biomedical research: looking through the articles published in a long-established histochemical journal}

\author{
C. Pellicciari \\ Department of Biology and \\ Biotechnology “Lazzaro Spallanzani”, \\ University of Pavia, Italy
}

\begin{abstract}
Histochemistry provides the unique opportunity to detect single molecules in the very place where they exert their structural roles or functional activities: this makes it possible to correlate structural organization and function, and may be fruitfully exploited in countless biomedical research topics. Aiming to estimate the impact of histochemical articles in the biomedical field, the last few years citations of articles published in a long-established histochemical journal have been considered. This brief survey suggests that histochemical journals, especially the ones open to a large spectrum of research subjects, do represent an irreplaceable source of information not only for cell biologists, microscopists or anatomists, but also for biochemists, molecular biologists and biotechnologists.
\end{abstract}

\section{Introduction}

During the last five years, more than 60,000 articles have been published where Histochemistry is present as MeSH (Medical Subject Headings) Term (see, http://www.ncbi.nlm.nih.gov/). This apparently demonstrates that histochemistry represents a key tool in biomedical research, for a wide variety of topics.

Obviously, the strictly histochemical Journals are the richest source of information for all those scientists who regularly use microscopy and histochemistry in their research; it is likely that these investigators included histochemical articles in the reference lists of the papers they have published.

In the attempt to estimate the impact of histochemical articles in the biomedical field, the last few years citations of articles published in the European Journal of Histochemistry have been considered. This sample may be taken as a reliable -though limited- reference, as the European Journal of Histochemistry, since its foundation in 1954 as the official organ of the
Italian Society of Histochemistry, accepts articles by scientists working in a wide variety of biological and medical fields, from cell and tissue biology, to microscopy, cytometry, zoology, human and veterinary medicine, ecology, botany. ${ }^{1}$

\section{How did the article subjects change in the European Journal of Histochemistry during the last 60 years}

At the risk of oversimplifying, the published articles have been arbitrarily divided into ten categories, based on the most frequently found subjects: i) Methods; ii) Neurobiology; iii) Connective tissue, bone \& cartilage; iv) Muscle tissue; v) Human pathology; vi) Animal biology \& Experimental medicine; vii) Development \& Stem cells; viii) Cell proliferation and death; ix) Human \& Comparative histology; x) Regenerative medicine. In Figure 1, the percentage of the different categories were reported considering the first ten years of publication of the Journal (1954 to 1963), the period $2000-2009$, and the last 5 years (2010-2014). In the first ten years of the journal, when histochemistry was living its pioneering age, there was a need to establish staining protocols and define the most appropriate experimental conditions for the application of histochemical techniques to different tissues from a variety of organisms: as a consequence of this intense effort, about $25 \%$ of the papers dealt with methods and techniques in the period 1954 to 1963 . The articles on Methods still represents about 13\% of the published ones since 2000 to present, and this demonstrates that a continuous adjustment and refinement of the analytical methods is necessary, to allow investigating heterogeneous cell and tissue models under different experimental conditions. ${ }^{2-13}$ Fluorescence microscopy and spectrofluorometry were used for localizing different chemical species, ${ }^{14,15}$ and for assessing changes in microenvironmental condition; ${ }^{14,16}$ it is worth noting the increasing attention for ultrastructural cytochemistry, which was used (often by multiplelabelling procedures) to detect specific molecules at high resolution. ${ }^{17-21}$

The most popular subjects (more than $40 \%$, as a whole) have always been Human pathology and Animal biology \& Experimental medicine; however, histochemistry was applied to very different targets, gradually over time. Descriptive articles on normal and pathological tissues in humans or animal species were very frequent in the first years, when the relatively poor knowledge of the molecular compo-
Correspondence: Carlo Pellicciari, Dipartimento di Biologia e Biotecnologie L. Spallanzani, Università di Pavia, via A. Ferrata 9, 27100 Pavia, Italy.

E-mail: pelli@unipv.it

Key words: Basic and applied histochemistry, Biomedical research.

Received for publication: 26 December 2014. Accepted for publication: 29 December 2014.

This work is licensed under a Creative Commons Attribution NonCommercial 3.0 License (CC BYNC 3.0).

\section{(C) Copyright C. Pellicciari, 2014}

Licensee PAGEPress, Italy

European Journal of Histochemistry 2014; 58:2474 doi:10.4081/ejh.2014.2474

sition of healthy and diseased organs made the detection in situ of different chemical components a very powerful diagnostic tool. Recently, most of the published articles aimed to identify diagnostic indicators ${ }^{22-33}$ or the progression markers ${ }^{34-37}$ of diseases, or at elucidating the pathogenetic molecular mechanisms ${ }^{38-45}$ as a methodological approach, (often multiple) immunohistochemical techniques were used.$^{46}$ On the contrary, the percentage of articles on the application of histochemistry to Neurobiology, Development \& stem cells, and Human \& Comparative histology did not change significantly in comparison with the long-past years. Immunohistochemical techniques were recently used to describe the topographical distribution of nerve cell populations in vertebrate and invertebrate species, ${ }^{47-51}$ and to investigate the effects of aging or experimentally-induced stress on the central nervous system. ${ }^{52-56}$ The maturation and elimination of oocytes was studied in mammals, ${ }^{57-59}$ while specific proteins were investigated during the pre- and neo-natal development, ${ }^{60-72}$ in particular of kidney $^{60,61}$ and heart. ${ }^{62,63}$ Descriptive articles have also been published on the expression of different molecules in Vertebrates organs. ${ }^{73-81}$

In recent times, the papers on Connective tissue, bone \& cartilage became numerous: this indicates that the histochemical approach is presently essential for studying structure and function of the hard tissues..$^{82,83}$ The unique structural characteristics of bone and cartilage makes it often necessary to use, in an integrated approach, immunocytochemistry, transmission and electron microscopy, as well as physical and biomolecular techniques. ${ }^{84-88}$ in several papers, qualitative and quantitative assays were used to study the dynamics of tooth repair both in vivo and in vitro, with special reference to the secretion and accumula- 
tion of dentin matrix proteins..$^{89-93}$

Based on histochemical findings at light and electron microscopy, it was hypothesized that common mechanisms may exist for the phenotypic characteristics of skeletal muscle cells in sarcopenia and myotonic dystrophy, ${ }^{94,95}$ and a very recent paper confirmed that premature senescence occurs in primary cultures of muscle cells from patients with myotonic dystrophy type $2 .{ }^{96}$ It has been demonstrated that an adapted physical exercise has positive effects on the structural features of both skeletal muscle cells and satellite cells:97-99 Molecular and ultrastructural analyses demonstrated that the myotendineous junctions are also able to positively adapt to stretching forces through the enlargement of the muscle-tendon contact area to increase mechanical resistance. ${ }^{100,101}$

A few papers only have been published on the cytochemical detection of Cell proliferation \& death, ${ }^{102-104}$ whereas it is worth noting that Regenerative medicine is presently gaining great attention. Most of the investigations are performed using cultured cells growing onto natural or artificial scaffoldings, where the interactions among grafted cells are essential for allowing growth and differentiation: this makes the analysis in situ of morphological, cytokinetic and molecular features essential for assessing the proliferation and reconstructive potential of cells in $2 \mathrm{D}$ and $3 \mathrm{D}$ cultures. ${ }^{105-108}$

\section{How the published articles did impact on the biomedical liter- ature}

In Figure 2, the impact of the papers published during the last five years was estimated; the articles have been pooled according to the ten categories listed above, and the percentage of citations for each category over the total number of quotations was calculated, for the same time span. As expected, the most cited articles (about $50 \%$ of the total) fall within Human pathology and Animal biology \& Experimental medicine, but a significant fraction of citations were for papers on Methods, Development \& stem cells and Human \& comparative histology.

Looking at the citations received by these articles in 2014 (Figure 3), Regenerative Medicine has the highest ratio of citations per published article, confirming that histochemistry may be regarded as a fundamental tool for studying cell interactions with the host tissues or the scaffolding structures, and for describing stem cell proliferation and differentiation. Actually, high ratios were also found

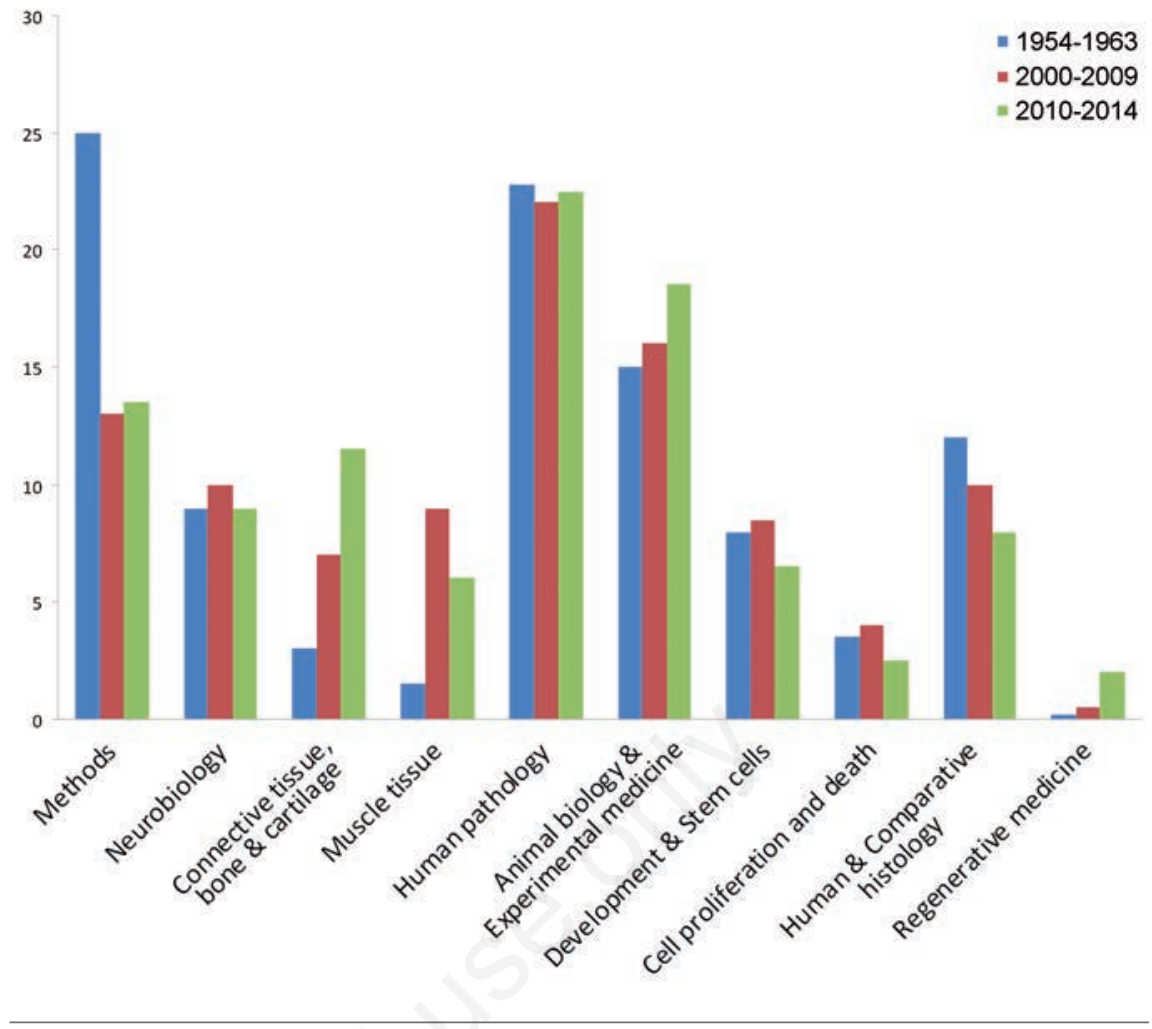

Figure 1. Percentage of articles published in the European Journal of Histochemistry in the three time periods, for the different subject categories.

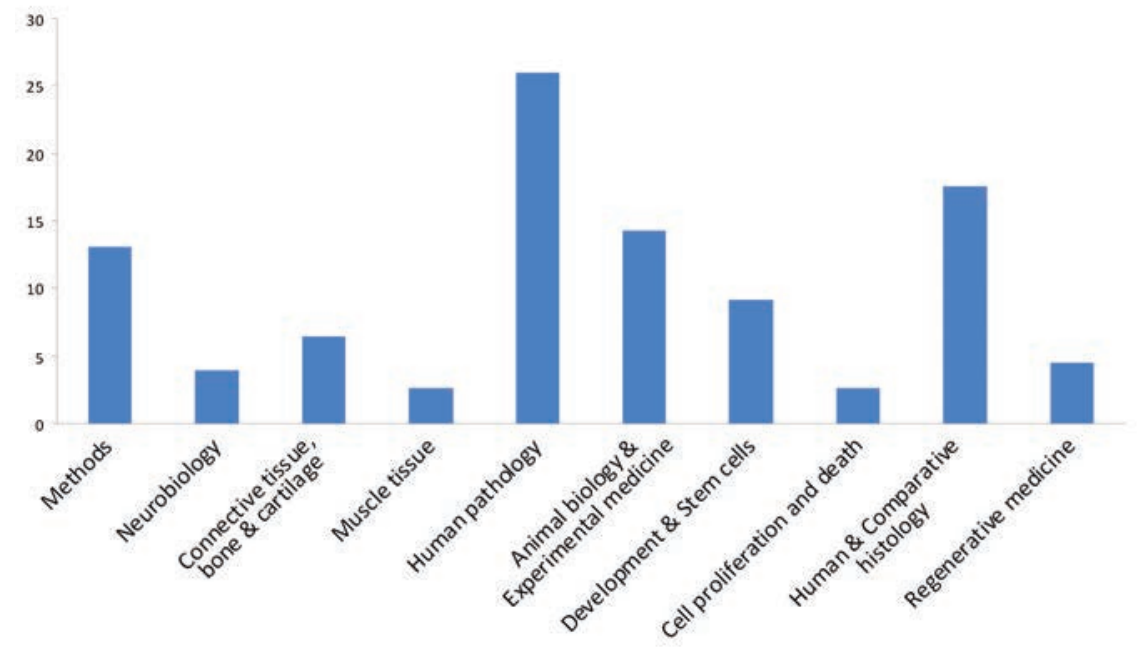

Figure 2. Percentage of citations for the different subject categories over the total number of quotations of the papers published in the European Journal of Histochemistry, during the last five years. 
for the articles published on Development \& stem cells and on Cell proliferation \& death. Unexpectedly, also the articles describing histological features in animal species and humans were highly cited.

To get a further indication of the influence of histochemical investigations on the different fields of biomedical research, in Figure 4 the citing articles of the last five years have been grouped according to the categories of the journals where they have been published, based on the subject categories listed in ISI web of knowledge - Journal Citation Reports.

As expected, most of the citing articles were published in journals of Microscopy and Cell biology, but the citing journals are scattered over a variety of categories, from Biochemistry \& Molecular biology to Reproductive biology, to Oncology and a series of specialized medical subjects, to Cell \& tissue engineering.

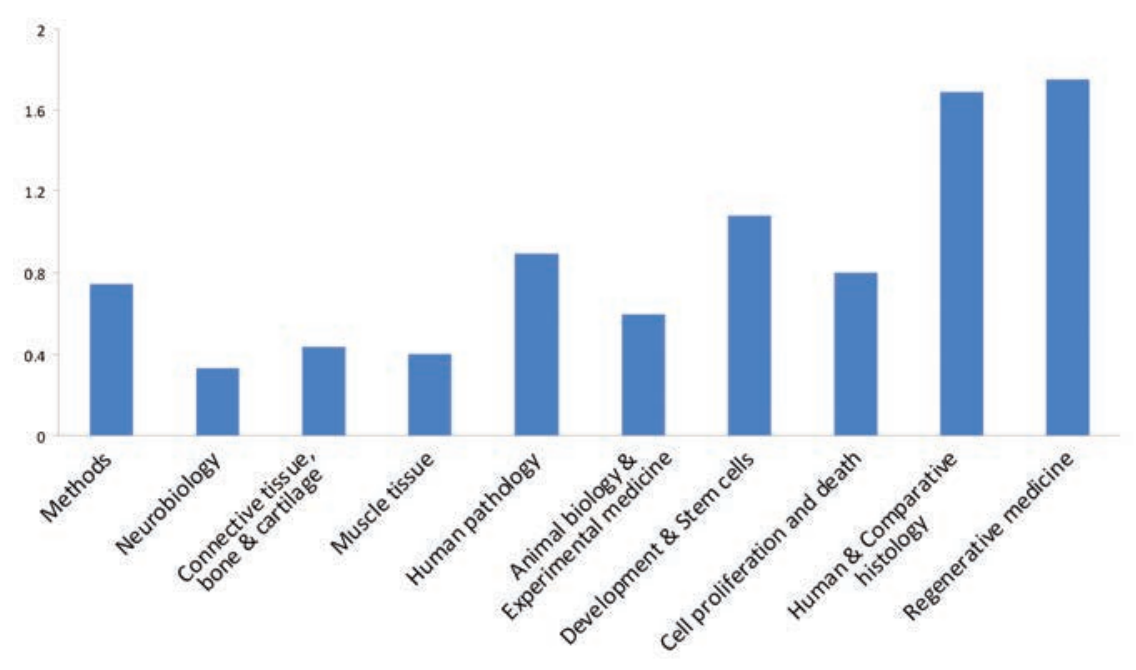

Figure 3. Percentage of citations received in 2014 by the articles published during the last five years in the European Journal of Histochemistry, considered per subject category.

\section{Microscopy \\ Cell biology}

Biochemistry \& molecular biology and Biochemical research methods

Neurosciences

Multidisciplinary sciences

Oncology

Reproductive biology

Cell \& tissue engineering and Biotechnology \& applied microbiology

Pharmacology \& pharmacy

Anatomy \& morphology

Pathology

Surgery and Dentistry, oral surgery

Dermatology

Endocrinology \& metabolism

Physiology

Urology \& nephrology

Hematology

Immunology

Medicine, research \& experimental

Ophthalmology

Orthopedics

Physics

Veterinary sciences


$+2$

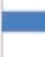

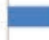

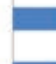




\section{Concluding remarks}

Histochemistry provides the unique opportunity to detect single molecules in the very place where they exert their structural roles or functional activities. This possibility to correlate structural organization and function may be fruitfully exploited in countless research subjects. Microscopy and histochemistry are appropriate tools for making correlations between microanatomy and physiology in tissues and organs, and the evidence obtained may be suitable for detecting pathological changes as well as for describing still poorly known organisms. A growing body of data showed that not only the expression of specific gene products but also their proper intracellular distribution is essential for the correct function of cells and tissues; again, histochemistry is appropriate for detecting ectopic relocation of molecular components, which often has diagnostic or predictive implications.

This limited survey confirms that histochemical journal, especially when open to a large spectrum of research subjects, do represent a matchless source of information for scientists in manifold research fields of biology and medicine. This was actually expected for cell biologists, microscopists or anatomists, but it is remarkable (though not surprising) that also biochemists, molecular biologists and biotechnologists do find suitable information in histochemical journals.

No doubt, Histochemistry nowadays is still live and in color. ${ }^{109}$

\section{References}

1. Pellicciari C. On the future contents of a small journal of histochemistry. Eur $\mathrm{J}$ Histochem 2012;56:e51.

2. Benerini Gatta L, Cadei M, Balzarini P, Castriciano S, Paroni R, Verzeletti A, et al. Application of alternative fixatives to formalin in diagnostic pathology. Eur $\mathrm{J}$ Histochem 2012;56:e12.

3. Rieger J, Twardziok S, Huenigen $\mathrm{H}$, Hirschberg RM, Plendl J. Porcine intestinal mast cells. Evaluation of different fixatives for histochemical staining techniques considering tissue shrinkage. Eur J Histochem 2013;57:e21.

4. Ami D, Di Segni M, Forcella M, Meraviglia V, Baccarin M, Doglia SM, et al. Role of water in chromosome spreading and swelling induced by acetic acid treatment: a FTIR spectroscopy study. Eur J Histochem 2014;58:2330.

5. Fassina L, Magenes G, Inzaghi A, Palumbo S, Allavena G, Miracco C, et al.
AUTOCOUNTER, an ImageJ JavaScript to analyze LC3B-GFP expression dynamics in autophagy-induced astrocytoma cells. Eur J Histochem 2012;56:e44.

6. Rizzatti V, Boschi F, Pedrotti M, Zoico E, Sbarbati A, Zamboni M. Lipid droplets characterization in adipocyte differentiated 3T3-L1 cells: size and optical density distribution. Eur J Histochem 2013;57: e24.

7. Perdoni F, Falleni M, Tosi D, Cirasola D , Romagnoli S, Braidotti P, et al. A histological procedure to study fungal infection in the wax moth Galleria mellonella. Eur J Histochem 2014;58:2428.

8. Kammoun M, Cassar-Malek I, Meunier B, Picard B. A simplified immunohistochemical classification of skeletal muscle fibres in mouse. Eur $\mathrm{J}$ Histochem 2014;58:2254.

9. Emde B, Heinen A, Gödecke A, Bottermann K. Wheat germ agglutinin staining as a suitable method for detection and quantification of fibrosis in cardiac tissue after myocardial infarction. Eur J Histochem 2014;58:2448.

10. Cabibi D, Giannone AG, Mascarella C, Guarnotta C, Castiglia M, Pantuso G, et al. Immunohistochemical/histochemical double staining method in the study of the columnar metaplasia of the oesophagus. Eur J Histochem 2014;58:2326.

11. Osman TA, Oijordsbakken G, Costea DE, Johannessen AC. Successful triple immunoenzymatic method employing primary antibodies from same species and same immunoglobulin subclass. Eur J Histochem 2013;57:e22.

12. Fede C, Fortunati I, Petrelli L, Guidolin D, De Caro R, Ferrante C et al. An easy-tohandle microfluidic device suitable for immunohistochemical procedures in mammalian cells grown under flow conditions. Eur J Histochem 2014;58:2360.

13. Bottone MG, Santin G, Soldani C, Veneroni P, Scovassi AI, Alpini C. Intracellular distribution of Tankyrases as detected by multicolor immunofluorescence techniques. Eur J Histochem 2012;56:e4.

14. Croce AC, Bottiroli G. Autofluorescence spectroscopy and imaging: a tool for biomedical research and diagnosis. Eur $\mathrm{J}$ Histochem 2014;58:2461.

15. Gomes F.M, Ramos I.B, Wendt C, GirardDias W, De Souza W, Machado E.A, et al. New insights into the in situ microscopic visualization and quantification of inorganic polyphosphate stores by 4 ',6diamidino-2-phenylindole (DAPI)-staining. Eur J Histochem 2013;57:e34.

16. Giansanti V, Santamaria G, Torriglia A, Aredia F, Scovassi AI, Bottiroli G, et al.
Fluorescence properties of the $\mathrm{Na}+\mathrm{H}+$ exchanger inhibitor HMA (5-(N,N-hexamethylene) amiloride) are modulated by intracellular pH. Eur J Histochem 2012;56:e3.

17. Derenzini M, Olins AL, Olins DE. Chromatin structure in situ: the contribution of DNA ultrastructural cytochemistry. Eur J Histochem 2014;58:2307.

18. Malatesta M, Giagnacovo M, Costanzo M, Conti B, Genta I, Dorati R, et al. Diaminobenzidine photoconversion is a suitable tool for tracking the intracellular location of fluorescently labelled nanoparticles at transmission electron microscopy. Eur J Histochem 2012;56:e20.

19. Malatesta M, Zancanaro C, Costanzo M, Cisterna B, Pellicciari C. Simultaneous ultrastructural analysis of fluorochromephotoconverted diaminobenzidine and gold immunolabeling in cultured cells. Eur J Histochem 2013;57:e26.

20. Grecchi S, Malatesta M. Visualizing endocytotic pathways at transmission electron microscopy via diaminobenzidine photooxidation by a fluorescent cell-membrane dye. Eur J Histochem 2014;58:2449.

21. Scimeca M, Orlandi A, Terrenato I, Bischetti S, Bonanno E. Assessment of metal contaminants in non-small cell lung cancer by EDX microanalysis. Eur J Histochem 2014;58:2403.

22. Santoro A, Pannone G, Errico ME, Bifano D, Lastilla G, Bufo P, et al. Role of $\beta$ catenin expression in paediatric mesenchymal lesions: a tissue microarraybased immunohistochemical study. Eur J Histochem 2012;56:e25.

23. Gurzu S, Krause M, Ember I, Azamfirei L, Gobel G, Feher K, et al. Mena, a new available marker in tumors of salivary glands? Eur J Histochem 2012;56:e8.

24. Galia A, Calogero AE, Condorelli R, Fraggetta F, La Corte A, Ridolfo F, et al. PARP-1 protein expression in glioblastoma multiforme. Eur J Histochem 2012;56:e9.

25. Zhang Y, Ye WY, Wang JQ, Wang SJ, Ji P, Zhou GY, et al. dCTP pyrophosphohydrase exhibits nucleic accumulation in multiple carcinomas. Eur J Histochem 2013;57: e29.

26. Soddu S, Di Felice E, Cabras S, Castellanos ME, Atzori L, Faa G, et al. IMP-3 expression in keratoacanthomas and squamous cell carcinomas of the skin: an immunohistochemical study. Eur J Histochem 2013;57:e6.

27. Cui C, Lal P, Master S, Ma Y, Baradet T, Bing Z. Expression of parafibromin in major renal cell tumors. Eur J Histochem 2012;56:e39.

28. Ferreira SA, Vasconcelos JL, Silva RC, 
Cavalcanti CL, Bezerra CL, Rego MJ, et al. Expression patterns of $\alpha 2,3$-sialyltransferase I and $\alpha 2,6$-sialyltransferase I in human cutaneous epithelial lesions. Eur J Histochem 2013;57:e7.

29. Salemi M, Galia A, Fraggetta F, La Corte C, Pepe P, La Vignera S, et al. Poly (ADPribose) polymerase 1 protein expression in normal and neoplastic prostatic tissue. Eur J Histochem 2013;57:e13.

30. Theunissen W, Fanni D, Nemolato S, Di Felice E, Cabras T, Gerosa C, et al. Thymosin beta 4 and thymosin beta 10 expression in hepatocellular carcinoma. Eur J Histochem 2014;58:2242.

31. Araujo DGB, Nakao L, Gozzo P, Souza CDA, Balderrama V, Gugelmin ES, et al. Expression level of quiescin sulfhydryl oxidase 1 (QSOX1) in neuroblastomas. Eur J Histochem 2014;58:2228.

32. Demirovic A, Cesarec S, Z. Marusic, Tomas D, M Milosevic, Hudolin T, et al. TGF- $\beta 1$ expression in chromophobe renal cell carcinoma and renal oncocytoma. Eur J Histochem 2014;58:2265.

33. Guerriero E, Accardo M, Capone F, Colonna G, G Castello, Costantini S. Assessment of the Selenoprotein M (SELM) over-expression on human hepatocellular carcinoma tissues by immunohistochemistry. Eur J Histochem 2014;58: 2433.

34. Ning J, Zhang J, Liu W, Lang Y, Xue Y, Xu $\mathrm{S}$. Overexpression of ubiquitin-specific protease 22 predicts poor survival in patients with early-stage non-small cell lung cancer. Eur J Histochem 2012;56: e46.

35. Zhang J, Luo J, Ni J, Tang L, Zhang HP, L Zhang, et al. MMP-7 is upregulated by COX-2 and promotes proliferation and invasion of lung adenocarcinoma cells. Eur J Histochem 2014;58:2262.

36. Lindström AK, Hellberg D. Immunohistochemical LRIG3 expression in cervical intraepithelial neoplasia and invasive squamous cell cervical cancer: association with expression of tumor markers, hormones, high-risk HPV-infection, smoking and patient outcome. Eur J Histochem 2014;58:2227.

37. Bułdak RJ, M Skonieczna, Bułdak L, Matysiak N, Mielańczyk L, Wyrobiec G, et al. Changes in subcellular localization of visfatin in human colorectal HCT-116 carcinoma cell line after cytochalasin B treatment. Eur J Histochem 2014;58:2408.

38. Zhu Y, Ning D, Wang F, Liu C, Xu Y, Jia X, et al. Effect of thyroxine on munc-18 and syntaxin-1 expression in dorsal hippocampus of adult-onset hypothyroid rats. Eur J Histochem 2012;56:e22.

39. Lattanzi G, Marmiroli S, Facchini A,
Maraldi NM. Nuclear damages and oxidative stress: new perspectives for laminopathies. Eur J Histochem 2012;56: e45.

40. Rappa F, Unti E, Baiamonte P, Cappello F, Scibetta N. Different immunohistochemical levels of Hsp60 and Hsp70 in a subset of brain tumors and putative role of Hsp60 in neuroepithelial tumorigenesis. Eur J Histochem 2013;57:e20.

41. Huang S, Guo S, Guo F, Yang Q, Xiao X, Murata $\mathrm{M}$, et al. CD44v6 expression in human skin keratinocytes as a possible mechanism for carcinogenesis associated with chronic arsenic exposure. Eur J Histochem 2013;57:e1.

42. Xu XC, Abuduhadeer X, Zhang WB, Li T, Gao H, Wang YH. Knockdown of RAGE inhibits growth and invasion of gastric cancer cells. Eur J Histochem 2013;57: e36.

43. Zhang Y, Tang YJ, Li ZH, Pan F, Huang K, $\mathrm{Xu} \mathrm{GH}$. KiSS1 inhibits growth and invasion of osteosarcoma cells through inhibition of the MAPK pathway. Eur $J$ Histochem 2013;57:e30.

44. V.N. Karavana, H. Gakiopoulou, E.A. Lianos Expression of Ser729 phosphorylated PKCepsilon in experimental crescentic glomerulonephritis: an immunohistochemical study. Eur J Histochem 2014;58:2308.

45. Asara Y, Marchal JA, Bandiera P, Mazzarello V, Delogu LG, Sotgiu MA, et al. Cadmium influences the 5-Fluorouracil cytotoxic effects on breast cancer cells. Eur J Histochem 2012;56:e1.

46. Pellicciari C, Malatesta M. Identifying pathological biomarkers: histochemistry still ranks high in the omics era. Eur $\mathrm{J}$ Histochem 2011;55:e42.

47. Kawashima M, Imura K, Sato I. Topographical organization of TRPV1immunoreactive epithelium and CGRPimmunoreactive nerve terminals in rodent tongue. Eur J Histochem 2012;56: e21.

48. Natale G, Pompili E, Biagioni F, Paparelli S, Lenzi P, Fornai F. Histochemical approaches to assess cell-to-cell transmission of misfolded proteins in neurodegenerative diseases. Eur J Histochem 2013;57:e5.

49. Pennati R, Dell'Anna A, Zega G, De Bernardi F. Immunohistochemical study of the nervous system of the tunicate Thalia democratica (Forsskal, 1775). Eur J Histochem 2012;56:e16.

50. Casini A, Vaccaro R, D'Este L, Sakaue Y, Bellier JP, Kimura H, Renda TG. Immunolocalization of choline acetyltransferase of common type in the central brain mass of Octopus vulgaris. Eur $\mathrm{J}$
Histochem 2012;56:e34.

51. Romero-Fernandez W, Borroto-Escuela D0, Vargas-Barroso V, Narváez M, Di Palma M, Agnati LF, et al. Dopamine D1 and D2 receptor immunoreactivities in the arcuate-median eminence complex and their link to the tubero-infundibular dopamine neurons. Eur J Histochem 2014;58:2400.

52. Damico JP, Ervolino E, Torres KR, Sabino Batagello D, Cruz-Rizzolo RJ, Aparecido Casatti C, et al. Phenotypic alterations of neuropeptide $\mathrm{Y}$ and calcitonin gene-related peptide-containing neurons innervating the rat temporomandibular joint during carrageenan-induced arthritis. Eur J Histochem 2012;56:e31.

53. Bolekova A, Kluchova D, Tomasova L, Hvizdosova N. Effect of retinoic acid on the nitrergic innervation of meibomian glands in rats. Eur $\mathrm{J}$ Histochem 2012;56:e50.

54. Lomoio S, Necchi D, Scherini E. Uneven distribution of NG2 cells in the rat cerebellar vermis and changes in aging. Eur $\mathrm{J}$ Histochem 2012;56:e27.

55. Salucci S, Ambrogini P, Lattanzi D, Betti M, Gobbi P, Galati C, et al. Maternal dietary loads of alpha-tocopherol increase synapse density and glial synaptic coverage in the hippocampus of adult offspring. Eur J Histochem 2014;58:2355.

56. Insolia V, Piccolini VM. Brain morphological defects in prolidase deficient mice: first report. Eur J Histochem 2014;58: 2417.

57. Luciano AM, Lodde V, Franciosi F, Tessaro I, Corbani D, Modina S. Large-scale chromatin morpho-functional changes during mammalian oocyte growth and differentiation. Eur J Histochem 2012;56:e37.

58. Khalili MA, Maione M, Palmerini MG, Bianchi S, Macchiarelli G, Nottola SA. Ultrastructure of human mature oocytes after vitrification. Eur $\mathbf{J}$ Histochem 2012;56:e38.

59. Escobar Sanchez ML, Echeverria Martínez OM, Vazquez-Nin GH. Immunohistochemical and ultrastructural visualization of different routes of oocyte elimination in adult rats. Eur $\mathrm{J}$ Histochem 2012;56:e17.

60. Fanni D, Iacovidou N, Locci A, Gerosa C, Nemolato S, Van Eyken P, et al. MUC1 marks collecting tubules, renal vesicles, comma- and S-shaped bodies in human developing kidney. Eur J Histochem 2012;56:e40.

61. Song JH, Lee MY, Kim YJ, Park SR, Kim J, Ryu SY, et al. Developmental immunolocalization of the Klotho protein in mouse kidney epithelial cells. Eur J Histochem 2014;58:2256. 
62. Zara S, Macchi V, De Caro R, Rapino M, Cataldi A, Porzionato A. pPKC $\alpha$ mediatedHIF- $1 \alpha$ activation related to the morphological modifications occurring in neonatal myocardial tissue in response to severe and mild hyperoxia. Eur J Histochem 2012;56:e2.

63. Zhao Y, Huang H, Jiang Y, Wei H, Liu P, Wang $\mathrm{W}$, et al. Unusual localization and translocation of TRPV4 protein in cultured ventricular myocytes of the neonatal rat. Eur J Histochem 2012;56:e32.

64. Shibata S, Fukuoka H, Sato R, Abe T, Suzuki Y. An in situ hybridization study of the insulin-like growth factor system in developing condylar cartilage of the fetal mouse mandible. Eur J Histochem 2012;56:e23.

65. Bradaschia-Correa V, Barrence FA, Ferreira LB, Massa LF, Arana-Chavez VE. Effect of alendronate on endochondral ossification in mandibular condyles of growing rats. Eur $\mathrm{J}$ Histochem 2012;56:e24.

66. San Martin S, Fitzgerald JS, Weber M, Párraga M, Sáez T, Zorn TM, et al. Stat3 and Socs3 expression patterns during murine placenta development. Eur J Histochem 2013;57:e19.

67. Godoy-Guzman C, San Martin S, Pereda J. Proteoglycan and collagen expression during human air conducting system development. Eur J Histochem 2012;56:e29.

68. Shibata S, Sakamoto Y, Baba 0, Qin C, Murakami G, Cho BH. An immunohistochemical study of matrix proteins in the craniofacial cartilage in midterm human fetuses. Eur J Histochem 2013;57:e39.

69. Kovsca Janjatovic A, Valpotic H, Kezic D, Lacković G, Gregorovic G, Sladoljev S, et al. Secretion of immunomodulating neuropeptides (VIP, SP) and nitric oxide synthase in porcine small intestine during postnatal development. Eur J Histochem 2012;56:e30.

70. Kovsca Janjatovic A, Valpotic H, Kezic D, Lacković G, Gregorovic G, Sladoljev S, et al. Secretion of immunomodulating neuropeptides (VIP, SP) and nitric oxide synthase in porcine small intestine during postnatal development. Eur J Histochem 2012;56:e30.

71. Sandhu MA, Saeed AA, Khilji MS, Pasha RH, Mukhtar N, Anjum MS. Ontogenic development of corticotrophs in fetal buffalo (Bubalus bubalis) pituitary gland. Eur J Histochem 2014;58:2292.

72. Bao L, Li Q, Liu Y, Li B, Sheng X, Han Y, et al. Immunolocalization of NGF and its receptors in ovarian surface epithelium of the wild ground squirrel during the breeding and nonbreeding seasons. Eur J
Histochem 2014;58:2363.

73. Kontro H, Hulmi JJ, Rahkila P, Kainulainen H. Cellular and tissue expression of DAPIT, a phylogenetically conserved peptide. Eur J Histochem 2012; $56: \mathrm{e} 18$.

74. Wang L, Wang J, Zhou X, Li J, Shi Y, Han $\mathrm{Z}$, et al. CM2 antigen, a potential novel molecule participating in glucuronide transport on rat hepatocyte canalicular membrane. Eur J Histochem 2012;56:e26.

75. Nemolato S, Ekstrom J, Cabras T, Gerosa C, Fanni D, Di Felice E, Locci A, et al. Immunoreactivity for thymosin beta 4 and thymosin beta 10 in the adult rat oro-gastro-intestinal tract. Eur J Histochem 2013;57:e17.

76. Tarantola E, Bertone V, Milanesi G, Capelli E, Ferrigno A, Neri D, et al. Dipeptidylpeptidase-IV, a key enzyme for the degradation of incretins and neuropeptides: activity and expression in the liver of lean and obese rats. Eur $\mathrm{J}$ Histochem 2012;56:e41.

77. Dorko F, Spakovská T, Lovasová K, Patlevič P, Kluchová D. NADPH-d activity in rat thymus after the application of retinoid acid. Eur J Histochem 2012;56: e7.

78. Latella G, Vetuschi A, Sferra R, Speca S, Gaudio E. $\alpha v \beta 6$ integrin-TGF- $\beta 1 / \mathrm{Smad} 3$, mTOR and PPARY in experimental colorectal fibrosis. Eur J Histochem 2013; $57: \mathrm{e} 40$.

79. Liu Y, Weng J, Huang S, Shen Y, Sheng X, Han $Y$, et al. Immunoreactivities of PPARY2, leptin and leptin receptor in oviduct of Chinese brown frog during breeding period and pre-hibernation. Eur J Histochem 2014;58:2422.

80. Akat E, Arıkan H, Göçmen B. Histochemical and biometric study of the gastrointestinal system of Hyla orientalis (Bedriaga, 1890) (Anura, Hylidae). Eur J Histochem 2014;58:2452.

81. Caprara GA, Perni S, Morabito C, Mariggiò MA, Guarnieri S. Specific association of growth-associated protein 43 with calcium release units in skeletal muscles of lower vertebrates. Eur J Histochem 2014;58:2453.

82. Kiga N. Histochemistry for studying structure and function of the articular disc of the human temporomandibular joint. Eur J Histochem 2012;56:e11.

83. Musumeci G, Castrogiovanni P, Mazzone V, Szychlinska MA, Castorina S, Loreto C. Histochemistry as a unique approach for investigating normal and osteoarthritic cartilage. Eur J Histochem 2014;58:2371.

84. Loreto C, Leonardi R, Musumeci G, Pannone G, Castorina S. An ex vivo study on immunohistochemical localization of MMP-7 and MMP-9 in temporomandibu- lar joint discs with internal derangement. Eur J Histochem 2013;57:e12.

85. Xu H, Zhang X, Wang H, Zhang Y, Shi Y, Zhang X. Continuous cyclic mechanical tension increases ank expression in endplate chondrocytes through the TGF- $\beta 1$ and p38 pathway. Eur $\mathbf{J}$ Histochem 2013;57:e28.

86. Xu HG, Zhang W, Q Zheng, Yu YF, Deng LF, Wang $\mathrm{H}$, et al. Investigating conversion of endplate chondrocytes induced by intermittent cyclic mechanical unconfined compression in three-dimensional cultures. Eur J Histochem 2014;58:2415.

87. Di Rosa M, Szychlinska MA, Tibullo D, Malaguarnera L, Musumeci G. Expression of CHI3L1 and CHIT1 in osteoarthritic rat cartilage model. A morphological study. Eur J Histochem 2014;58:2423.

88. Shinohara Y, Okamoto K, Goh Y, Kiga N, Tojyo I, Fujita S. Inhibition of fibrous adhesion formation in the temporomandibular joint of tenascin-C knockout mice. Eur J Histochem 2014;58:2337.

89. Carvalho-Filho EP, Stabile AC, Ervolino E, Stuani MB, Iyomasa MM, Rocha MJ. Celecoxib treatment does not alter recruitment and activation of osteoclasts in the initial phase of experimental tooth movement. Eur J Histochem 2012;56:e43.

90. Martini D, Trirè A, Breschi L, Mazzoni A, Teti G, Falconi M, et al. Dentin matrix protein 1 and dentin sialophosphoprotein in human sound and carious teeth: an immunohistochemical and colorimetric assay. Eur J Histochem 2013;57:e32.

91. Teti G, Salvatore V, Ruggeri A, Manzoli L, Gesi M, Orsini G, et al. In vitro reparative dentin: a biochemical and morphological study. Eur J Histochem 2013;57:e23.

92. Orsini G, Majorana A, Mazzoni A, Putignano A, Falconi M, Polimeni A, et al. Immunocytochemical detection of dentin matrix proteins in primary teeth from patients with dentinogenesis imperfecta associated with osteogenesis imperfecta. Eur J Histochem 2014;58:2405.

93. Loreto C, C Galanti, Musumeci G, Rusu MC, Leonardi R. Immunohistochemical analysis of matrix metalloproteinase-13 in human caries dentin. Eur J Histochem 2014;58:2318.

94. Malatesta M. Skeletal muscle features in myotonic dystrophy and sarcopenia: do similar nuclear mechanisms lead to skeletal muscle wasting? Eur J Histochem 2012;56:e36.

95. Malatesta M, Giagnacovo M, Costanzo M, Cisterna B, Cardani R, Meola G. Muscleblind-like1 undergoes ectopic relocation in the nuclei of skeletal muscles in myotonic dystrophy and sarcopenia. Eur J Histochem 2013;57:e15. 
96. Renna LV, Cardani R, Botta A, Rossi G, Fossati B, Costa Eet al. Premature senescence in primary muscle cultures of myotonic dystrophy type 2 is not associated with p16 induction. Eur J Histochem 2014;58:2444

97. Malatesta M, Fattoretti P, Giagnacovo M, Pellicciari C, Zancanaro C. Physical training modulates structural and functional features of cell nuclei in type II myofibers of old mice. Rejuvination Res 2011;14: 543-52.

98. Hagen KB, Dagfinrud H, Moe RH, Osteras $\mathrm{N}$, Kjeken I, Grotle M, et al. Exercise therapy for bone and muscle health: an overview of systematic reviews. BMC Med 2012;10:167.

99. Montero-Fernández N, Serra-Rexach JA. Role of exercise on sarcopenia in the elderly. Eur J Phys Rehabil Med 2013;49:131-43.

100. Curzi D, Salucci S, Marini M, Esposito F, Agnello L, Veicsteinas A, et al. How physical exercise changes rat myotendinous junctions: an ultrastructural study. Eur J Histochem 2012;56:e19.

101. Curzi D, Lattanzi D, Ciuffoli S, Burattini
S, Grindeland RE, Edgerton VR, et al. Growth hormone plus resistance exercise attenuate structural changes in rat myotendinous junctions resulting from chronic unloading. Eur J Histochem 2013;57:e37.

102. Donizy P, Halon A, Surowiak P, Pietrzyk G, Kozyra C, Matkowski R. Correlation between PARP-1 immunoreactivity and cytomorphological features of parthanatos, a specific cellular death in breast cancer cells. Eur J Histochem 2013;57:e35.

103. Chiusa M, Timolati F, Perriard JC, Suter TM, Zuppinger C. Sodium nitroprusside induces cell death and cytoskeleton degradation in adult rat cardiomyocytes in vitro: implications for anthracyclineinduced cardiotoxicity. Eur J Histochem 2012;56:e15.

104. Ou JM, Yu ZY, Qiu MK, Dai YX, Q Dong, Shen J, et al. Fei Knockdown of VEGFR2 inhibits proliferation and induces apoptosis in hemangioma-derived endothelial cells. Eur J Histochem 2014;58:2263.

105. Lehmann M, Martin F, Mannigel K,
Kaltschmidt K, Sack U, Anderer U. Threedimensional scaffold-free fusion culture: the way to enhance chondrogenesis of in vitro propagated human articular chondrocytes. Eur J Histochem 2013;57:e31.

106. Tetè S, Vinci R, Zizzari VL, Zara S, La Scala V, Cataldi A, et al. Maxillary sinus augmentation procedures through equine-derived biomaterial or calvaria autologous bone: immunohistochemical evaluation of OPG/RANKL in humans. Eur J Histochem 2013;57:e10.

107. Porzionato A, Sfriso MM, Macchi V, Rambaldo A, Lago G, Lancerotto L, et al. Decellularized omentum as novel biologic scaffold for reconstructive surgery and regenerative medicine. Eur J Histochem 2013;57:e4.

108. Dall'Oca C, Maluta T, Cavani F, Morbioli GP, Bernardi P, Sbarbati A, et al. The biocompatibility of porous vs non-porous bone cements: a new methodological approach. Eur J Histochem 2014;58:2255.

109. Lavis LD. Histochemistry: live and in color. J Histochem Cytochem 2011;59: 139-45. 